\title{
Narrative interviews in research on post-war socio-historical processes as formative factors of regional identity of the population - Case study of the Svitavy region, Czech Republic
}

\author{
PAVlína SLOVÁKOVÁ ${ }^{1}$ and MilosLav ŠERÝ ${ }^{2}$
}

\begin{abstract}
The aims of the paper are twofold. The first aim is a methodological one, the article presents the possibilities of using narrative interviews in research on post-war socio-historical development. The second aim is to evaluate the experiences of eyewitnesses who experienced the expulsion of the German-speaking population and the process of resettlement in the distinctive region of Svitavy. Being the largest migratory population movement in the $20^{\text {th }}$ century in the Czech lands, the displacement of the Germans and the subsequent process of resettlement brought significant social, cultural, and economic consequences. Their influence on the inhabitants of the affected regions and regional identities of these inhabitants is evident even now. The method of narrative interviews contributes to unveiling the importance of these processes in witnesses' minds. The successful fulfilment of both objectives allows evaluation of the appropriateness of the methods applied in research on regional identities of the population, as well as a better understanding of the importance of post-war events for the eyewitnesses to them. As these events occurred in a specific region (Svitavy), it is possible to identify important factors that contributed to the formation of regional identities of these witnesses. The article is a contribution to the existing knowledge about the phenomenon of regional identity of populations, which is understood as a process. In addition, it also contributes to a deeper knowledge of the role of the (dis)continuity of settlement in this process.
\end{abstract}

Keywords: narrative interview, regional identity of population, migration, Svitavy region, Czech Republic, transfer of Germans from Czechoslovakia

\section{Introduction}

The transfer of the German population from Czechoslovakia and the subsequent resettlement of the borderland by inhabitants of mostly Czech nationality is a subject that is still to some extent controversial and is widely discussed (STANĚK, T. 1991; KuraL, V. 1994; BENEš, Z. 2002; ČAPKA, F. et al. 2005; von Arburg, A. and StanĚK, T. 2010). In addition to debates about the correctness of the transfer of the German citizens, its manner and course, and the possibly rather chaotic course of the subsequent resettlement, recent discussions have also focused on the social, cultural, and economic consequences of the largest migratory movements of the population in the Czech Republic in recent history. A partial interest in the evaluation of the possible consequences of such continuity up to the present day is also evident within Czech geographical research projects (DANĚK, P. 2000; Chromý, P. and Skála, J. 2010; KuČera, Z. and KuČerová, S. 2012; Šerý, M. and ŠimáčeK, P. 2013; Š ERÝ, M. 2014).

However, research on the very development and immediate effects of the above migratory movements has remained somewhat out of the spotlight of Czech geographers. For research on the actual intensity

\footnotetext{
${ }^{1}$ Department of Geography, Faculty of Science, Masaryk University, Kotlářská 2, 61137 Brno, Czech Republic. E-mail: pzrustova@mail.muni.cz

${ }^{2}$ Department of Geography, Faculty of Science, Palacký University Olomouc, 17. listopadu 12, 77146 Olomouc, Czech Republic. E-mail: serymilos@gmail.com
} 
of the migration flows and their spatial differences, as well as the social and economic structure of the population that participated in these migrations, the statistical sources of data from the pre-war and post-war periods are very important. Here we mean primarily three censuses in the Czechoslovak Republic (1 December 1930, 1 March 1950 and 1 March 1961) (State Statistical Office 1935a,b, 1955, 1966), the Survey of Municipalities in the Bohemian and Moravian-Silesian lands of December 1, 1945 (State Statistical Office 1946), and, last but not least, the Registers of Citizens in Czechoslovakia in 1946 and 1947 (State Statistical Office 1951). Using these resources of aggregate, quantitative data we can gain a general idea of the abovementioned processes and these ideas can be combined with archival research, which is particularly desirable at regional level. This approach, which allows us to create a more synoptic image of the post-war development, has been used by authors (SKŘIVÁNEK, M. 1995; KáŇA, O. 1976) who strove to analyse the issue in question within their case studies of selected border regions.

However, if we seek a more comprehensive understanding of the processes of the transfer of the German-speaking citizens and the resettlement, the specific regional features, and the consequences so far, we have to extend the above-mentioned methods. We consider one of the alternative approaches to be the method of narrative interview with people who lived through these processes, or at least were affected by these processes. The method of narrative interview has the potential to identify phenomena that are hard to understand. Here we mean primarily the perception of post-war processes by eyewitnesses to them, mostly based on their own experience of these processes, which determines the future development and formation of a number of aspects.

These must include the relationship of individuals to the area they live in, or the level of identification with the community which the individual is a part of. We should not forget the perception and understanding of the symbolism that represents this living space. Similarly, the post-war experience may have affected the willingness of individuals to participate in the organisation and functioning of institutions that are linked to their living space. If we start from the intentions of the new regional geography (THRIfT, N. 1983; Pred, A. 1984), all these aspects can be understood as essential dimensions of the phenomenon of regional identity of the population (PAAsI, A. 1986, 2002), which has been developed, reproduced, and transformed on a long-term basis (Macleod, G. 1998).

Despite the potential of narrative interviews to facilitate the understanding of the formative factors of regional identity of a population (HoužvičKa, V. and Novotný, L. 2007), this method does not have a strong position in research carried out in the framework of Czech geography so far. Therefore, the first (methodological) objective of this paper is to evaluate the importance of narrative interviews for research on the formative factors of regional identity of population.

The second objective of the paper is then to assess the specific formative factors of regional identity of population, which include the experience of eyewitnesses of the resettlement of the German-speaking population and the colonisation process in the Svitavy region.

To meet the above objectives successfully, we will seek answers to the following research questions:

a) To what extent is the narrative interview an appropriate method to gain qualitative data on phenomena shaping the process of regional identity of the population?

b) What is the opinion of witnesses to the post-war resettlement of the German-speaking population? Did they maintain friendly relations with the German-speaking inhabitants before the war and after it?

c) Did the respondents themselves participate in the colonisation process? How do they evaluate this process?

We believe that by fulfilling the objectives of the paper, we can methodologically and factually enrich the existing geographic re- 
search focused on the possibility of understanding the above-mentioned formative factors in the process of the creation of regional identity of the population. In addition, one part of the Svitavy region faced the post-war migrations while another part of it was not affected by these transfers, and, on the contrary, served as the source area for the resettlement. Thanks to this, it is possible to understand Svitavy as a distinctive region with an internally differing continuity of socio-historical development. As a result of this nature of the region in question, the fulfilment of the above objectives may also contribute to a better understanding of the role of the dis-/continuity of settlement in the process of the creation of regional identity of the population.

\section{Methodological aspects of narrative interviews}

In the social sciences, qualitative research indicates the type of research that focuses on how individuals and groups perceive, understand, and interpret the world. According to other criteria, qualitative research is research that does not use statistical methods or techniques. In this concept, it is contrasted with quantitative research, which is not suitable for research conducted on a smaller scale, when the categories and theories applied by a researcher may not correspond to local particularities or the knowledge that is acquired is too abstract and general for direct application in local conditions. A researcher may also be limited by a reductive method of data acquisition (HENDL, J. 2008).

The most widely used qualitative methods in geographical research include direct observation, participant observation, grounded theory, keeping a research diary, and, especially, interviewing subjects. These methods are potentially able to provide the data needed for a research study (HendL, J. 1997). The way in which the subjects are interviewed may vary, depending on the object and purpose of the research, the nature of the survey data, or, for example, on the time capacity and financial resources of the researcher. As DunN, K. (2005: 79) states, interviews are verbal interchanges where one person, the interviewer, attempts to elicit information from another person. On the one hand, we can use a precisely structured questionnaire, which results in easily comparable answers; on the other hand, a free interview without a predetermined structure and with only a primary topic of conversation may also be an appropriate method (HendL, J. 2005). A compromise between these two methods is a semi-structured interview (LoNGHURst, R. 2010).

A narrative interview is based on the free narration of the person being interviewed, with important information being reflected by the interviewer only during the interview. This open type of interview is based on the assumption that narration has been an essential component of human communication since the very beginning of modern civilisation and describes the everyday activities and problems of an individual in the best possible way.

As already mentioned, the narrative interview can be structured, semi-structured, or completely unloaded with any structure, with the interviewer responding exclusively to the narration of a particular respondent (GIVEN, L.M. 2008). The nature of the narrative interview is strongly interdisciplinary. The respondents' experience and the information obtained during the interview are a useful source of data for sociology, psychology, geography, philosophy, and cultural studies, but, in a sense, also for economic and marketing disciplines (WENGRAF, T. 2001).

According to Sснütze, F. (1987), who was the first to describe the narrative interview method, the form of the interview consists of several stages. First, it is important to inform the respondent about the topic of the interview and the reason why it is being conducted. It is necessary to inspire confidence and make the interviewee interested so that he/she tries to recall events that might not be mentioned in direct questioning.

At the stage of the actual narration, the interviewer should not interrupt the inter- 
viewee's monologue, but only listen intently, and use gestures or not to invoke a feeling of concernedness and being interested in the story being narrated. After the end of the narration, it is appropriate to use narrativising questions that respond to the events mentioned by the interviewee and aim to develop them in a certain direction.

The prerequisite for these questions is the expectation of further narration. From the experience of other interviews, the questions can be formulated in a way that takes into account the information received from the other interviewees, but has not been mentioned by the current respondent. After all the topic-related questions have been exhausted, the interview should continue with additional descriptive characteristics of the persons presented in the story, with an effort to relate the events that have been described and their possible consequences to the present (Jovchelovitch, S. and Bauer, M.W. 2000; Bates, J.A. 2005).

The purpose of the narrative interview is the rejection of the classical scheme of the question-answer type of interview and, on the contrary, minimum communicative involvement of the interviewer in the narration. The positive effect of the narrative interview is the presentation of events in the life of the interviewee in his/her own words, which, according to the supporters of the narrative interview approach, could not be covered during a normal structured interview (Jovchelovitch, S. and Bauer, M.W. 2000; AtKinson, R. 2001).

The narrative interview is primarily used to capture the course of events that took place in the past, which develops in a certain way. This is an important feature of the method with regard to the fact that regional identity of the inhabitants is always rooted in the past (Graham, B. 2000) and its formative factors are subjected to developmentally continuous reproduction and transformation (VAINIKKA, J. 2012).

On the contrary, the narrative interview approach is totally inappropriate if the researcher requires obtaining quantitative in- formation or opinions on phenomena that are not related directly to the respondent and his/her story. The essence of a narrative interview is his/her experience and subjective perception of facts that influenced the interviewee to some extent and to which he/she attaches some weight. The advantage of the narrative interview is in its putting the emphasis on the individual and his/her subjective perception of processes and phenomena in time and space, against the background of a characteristic social framework.

Jovchelovitch and BAuer (2000) pointed out two problematic aspects of narrative interviews. The person being interviewed can create his/her own hypothesis about what the interviewer wants to hear and what he/she probably already knows.

The consequence can be partially conscious non-disclosure of information which would represent a contribution to the research. They may also show some doubts about the phases of a narrative interview. In particular, difficulty in stimulating the interest of the person being interviewed in the topic relates largely to the experience of the interviewer and the narrative part itself is then heavily influenced by the confidence in the researcher and his/ her work.

It is also important to understand that for many people the narration itself, on which the whole interview is based, may be an unnatural activity that is not easy to manage. Another important factor is the process of forgetting, which is influenced by many factors, e.g. protection of mental capacity from overload and congestion, a long period of time having passed since the event happened, or an effort to displace unpleasant memories (Č̌rMáK, I. et al. 2007).

The data processing (time-consuming transcription) and especially the evaluation of the interviews are relatively difficult. From the huge amount of the texts of the interviews, it is necessary to select only those pieces of information that are relevant for the research, which are then broken down in an appropriate manner according to their content and compared with each other (BATES, J.A. 2005). 
Narrative interview and geographical research on regional identity of populations

In geography, qualitative research methods are relatively widespread and the qualitative approach is certainly not unknown to geographers interested in issues of regional identity (KNeAfSEY, M. 2000; Everett, S. and Aitchison, C. 2008; Antonsich, M. 2010; Zimmerbauer, K. 2011). According to Wiles, J.L. et al. (2005), semi-structured interviews are widely used, while much less attention is paid to alternative methods of investigation. These methods include the narrative interview, which is suitable for the detection of facts that are unobtainable from other available sources.

Because of this feature and the characteristics of the method described in the previous chapter, we attempted to use the narrative interview approach in our research on regional identity of the population of the Svitavy region. More precisely, this method was used to identify the way in which the post-war experience can influence the process of the creation of regional identity of the inhabitants of the area concerned.

The specific features of the coexistence of two or more nationalities in certain regions have their roots in the distant past and have undergone many changes during the development of the region.

The form of a free and open interview can help to gain an understanding of the unique feelings, perceptions, and opinions of the inhabitants of the border areas regarding the dramatic post-war events that are often difficult to describe objectively and analyse as a result of the lack of a sufficient amount of data and sources.

Although the subjectivity of those interviewed is considerable, the information obtained through narrative interview can paradoxically be used to add greater objectivity to the research (Jovchelovitch, S. and BAUER, M.W. 2000).

For example, we can start from the assumption that we have only inaccurate statistics on a certain village affected by the transfer of its German inhabitants with regard to the number that were transferred and a few references on the course of the displacement found in archival materials or a secondary publication that deals with this topic.

The narration of the witnesses may to some extent explain the course and the circumstances of the involuntary exodus of the German population, especially in those cases where the statements of individual interviewees overlap or coincide. The experiences and memories of witnesses are often the only source of information and, though they should be treated with critical distance, are priceless for research on the conditions under which regional identity of the population was formed.

\section{Regional identity of inhabitants}

From a broader perspective the very existence of regional identity of a population can be understood as a manifestation of human needs, specifically, the need to belong somewhere, which Masnow, A.H. (1943) sees as the most important social need of any individual.

Through a successful fulfilment of this need, a person gets an idea of his/her position and role in a complex environment and builds and realises his/her own identity. If the sources of the identity of individual persons and the process of the creation of these identities show the same characteristics, we can talk about the generation of collective identity.

The concept of collective identities and the processes of their formation are tackled by Cerulo, K.A. (1997: 386), who suggests that, so rooted, the notion addresses the "we-ness" of a group, stressing the similarities or shared attributes around which group members coalesce.

The above-mentioned attributes can be determined, for example, by ethnicity, religiosity, sexuality, cultural characteristics, and, last but not least, by spaciousness. Spaciousness consists of the daily activities of people within the various spatial categories, either 
in particular places (TuAN, Y.-F. 1974; RELPH, E. 1976) or regions (PAASI, A. 2002). ${ }^{3}$ Spatial categories are then used in the process of building human identities. In this context, regional identity of a population can therefore be understood as one of the essential forms of collective identity.

Regional identity of a population is a relatively complex and elusive phenomenon. In this paper, we start from the conceptualisation established by PAAsI, A. (1986). Its essence is the classification of this phenomenon within three subsets. The first one is identification with regional group or community. This subset consists of both the factual identification and the ideal identification.

The former is based on actual relationships between individuals who are in some way connected with the region. In this case of community, an important fact is that the individuals are acculturated and are familiar with structures of expectations. In the latter case we are talking about a certain image of identification, which is communicated and represented in the institutional practice of the region and its community. In the latter case, the purpose is the reproduction of awareness of regional community.

Typically, these two types of identification are not in agreement, but this discrepancy does not preclude their importance for the formation of regional identity of the population. In the post-war period, it is possible to observe tangible differences between the factual identification and ideal identification of the population in a number of Czech regions. These were mainly the border regions affected by the replacement of their residents.

This process brought about a transformation of the factual identification with the community, as well as of the ideal identification with the community, in the latter case mostly as a result of the influence of regional institutions (the press, etc.) that responded to the newly created conditions. These transformations significantly determined the further

\footnotetext{
${ }^{3}$ For the conceptualisation of the relationship between a region and a particular place, see, for example, PAasi, A. 1986, 2002; Chromý, P. 2003; ŠErŕ, M. 2014.
}

formation of regional identity of the local residents.

Besides the idea of community, the individual components of regional identity of the population also include the process of the identification of the population with the region. This process helps the residents to attribute the role of the region in regional hierarchy of consciousness, which PAAsI, A. (1986) considers to be a second subset of regional identity of the inhabitants of the region. The third formative subset of regional identity is the so-called image of the region. This subset is formed not only by the population of a particular region but also by the communities living outside the region, which logically leads to discrepancies: the image of a region sensed inside the region usually differs from the external image of the region. However, these different images influence the broader concept of regional identity rather than regional identity of the population of a particular region.

None of the three above-mentioned components of regional identity of the population can be understood as static entities. On the contrary, they are dynamic aspects that develop in a long-term process, in the course of which the final form of regional identity of the population can consciously or unconsciously (Zich, F. 2007) be consolidated or transformed, or even cease to exist in extreme cases. Regional identity as a process is shaped by a number of formative factors. These factors include the experience of postwar migration events. These seemingly distant experiences in fact virtually continue to function in the minds of individuals in the form of individual historical consciousness, which has an obvious relationship to the formation of regional identity of the population (HoužvičKa, V. and Novotný, L. 2007).

\section{Brief characteristics of the region under study}

The Svitavy region, a district officially established in 1960, was chosen as the area of interest for several reasons. Svitavy is an example of an area that is historically hetero- 
geneous, with different territorial, administrative and linguistic affiliations. Half of its territory was part of the largest German language island in the Czechoslovak Republic (hereinafter CSR) called Hřebečsko, while the Czechs and Germans coexisted here from the mid-13 ${ }^{\text {th }}$ century (Fikejz, R. 2003). The area of interest is crossed by the relict land border between Bohemia and Moravia. The political districts of Litomyšl and Polička lay in Bohemia, while the political district of Moravská Třebová, which was formed by the sub-districts of Svitavy, Moravská Třebová, and Jevíčko, belonged to Moravia (Маскоvá, M. 2009). The border was deinstitutionalised in 1949 in connection with extensive administrative changes (DANIEL, J. 2013).

The above-mentioned political districts were maintained, while the boundary between Bohemia and Moravia, which was deinstitutionalised at the same time, was respected. With effect from 1960, when a major administrative reform was adopted, the existence of the relict land border was not respected and a new district structure was established. One of them was the Svitavy district, into which all the above-mentioned political districts (Litomyšl, Moravská Třebová, and Polička) were integrated. Therefore, the new district of Svitavy was crossed by the relict land border (Figure 1).

In Figure 2 it can be seen clearly that the linguistic border, which has been also relict but was not, however, identical with the land border, because there were also German municipalities located on the Bohemian side of the area of interest. Svitavy district cannot be described as a "typical" border or inland district (according to various definitions only a part of the today's district was defined as a borderland).

From a historical point of view, the Czech borderland may be defined as an area of pre-war German settlement. According to the Decree of President Beneš no. 121/1945 Coll. on the territorial organisation of administration carried out by national committees, as well as according to a definition of borderlands by the Resettlement Office in June 1946, the political district of Moravská Třebová was included in the borderland, while the districts of Polička and Litomyšl were not (VELEŠíK, V. 2000).

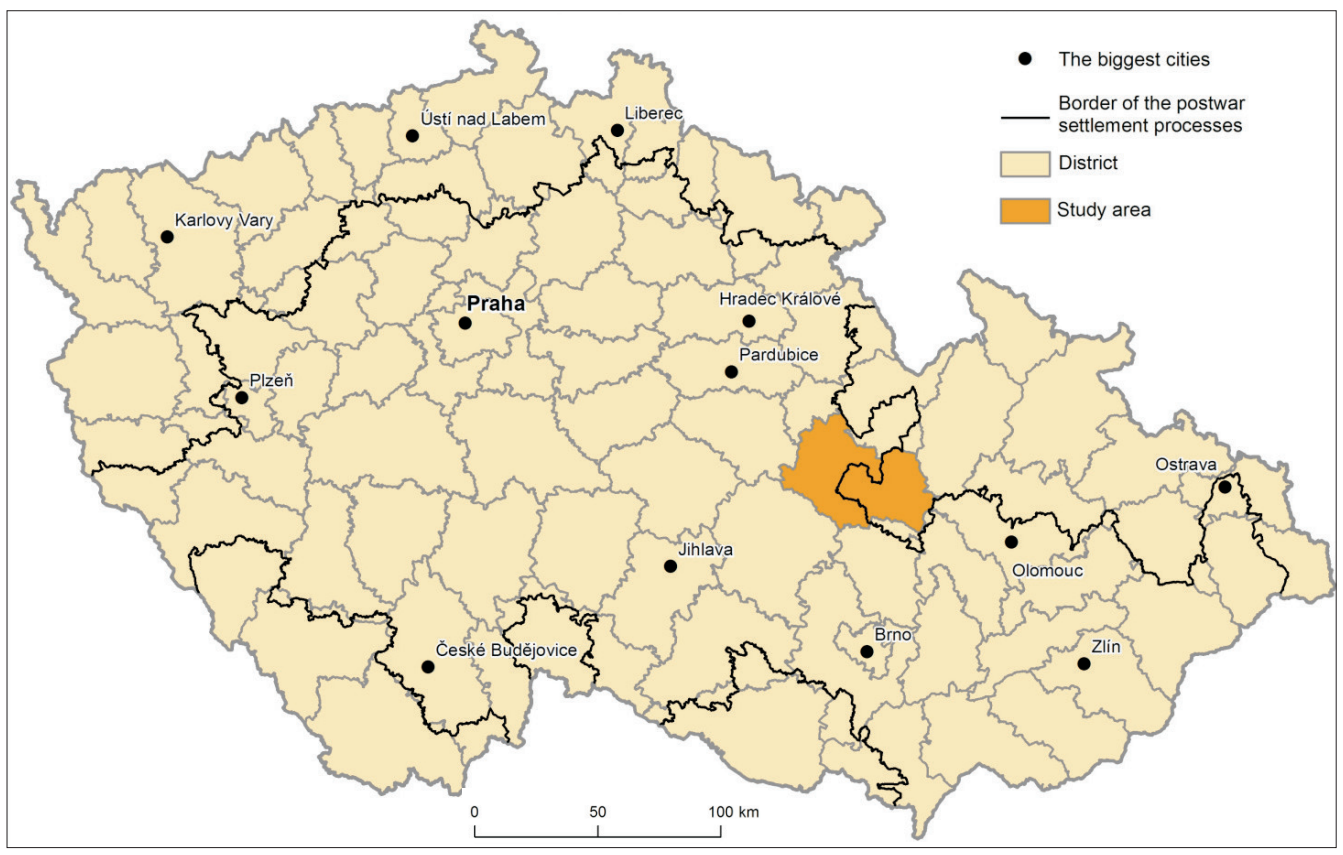

Fig. 1. The area under study. Source: ČAPKA, F., SLEZÁk, L. and VACulík, J. 2005. Authors' own processing 


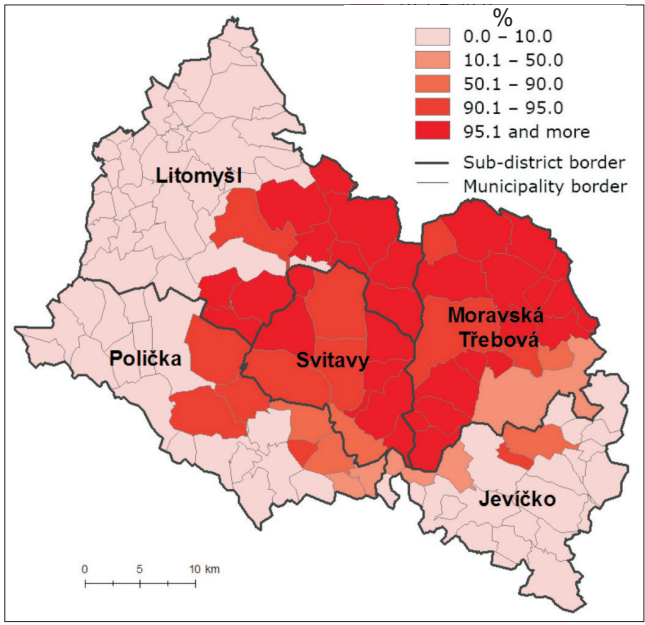

Fig. 2. The proportion of German speaking population in the municipalities of the area under study in 1930. Source: State Statistical Office 1934, 1935. Authors' own processing

In connection with the borderland, the terms Sudetenland or external border regions are also used to describe the area affiliated to the German Reich (the district of Moravská Třebová). (The term Sudetenland has a more complicated history and is used in different contexts, see KRÁL, V. 1992.) The complicated history, heterogeneous nature of the region, and uneven development of its nationalities together created the distinctive nature of the region, lying in the inner dichotomy of the continuity of its socio-historical development (Figure 2).

In 1930 the districts of Moravská Třebová, Svitavy, Jevíčko, and Litomyšl were inhabited by 156,506 people in total, of whom 72,400 were of German nationality. After the war, in the summer months of 1945, about 21,000 Germans became victims of unorganised transfer, which, from regional perspective, was part of the "cleanup" of the Hřebečsko linguistic island. During the "organised transfer" which took place in the period 1946-1947, about 46,000 German inhabitants left the area in three stages (SKŘIVÁNEK, M. 1995). Simultaneously with the transfer, the region was resettled with a new population. However, the overall quota set for the newly arriving inhabitants was not fulfilled and in certain municipalities there was a lack of interest in resettlement. In May 1947, only 119,147 inhabitants lived in this territory, which is a quarter less than in 1930. In resettled municipalities, the population was 43 percent lower than before the war. The number of inhabitants also dropped in Czech municipalities not affected by the transfer as a result of their participation in the resettlement process and ongoing urbanisation trends (Table 1).

Between 1930 and 1961 the area in question underwent complex economic, social, and demographic changes and also, as a result of some administrative changes, suffered a loss of about a third of its population, which turned out to be permanent, with the numbers remaining more or less the same until today. Considering the fact that this region is partly influenced by the historical factor of a population exchange after the Second World War and the resettlement of municipalities and homesteads whose previous owners differed from the new settlers in terms of nationality, way of life, internal culture, and

Table 1. Number of inhabitants in selected districts

\begin{tabular}{l|r|r|r|r|r}
\hline \multirow{2}{*}{ Administrative district } & \multicolumn{3}{|c|}{ Number of inhabitants } & \multicolumn{1}{c}{$\begin{array}{c}1961 / 1930 \\
\text { rate in \% }\end{array}$} \\
\cline { 2 - 5 } & 1930 & 1947 & 1950 & \multicolumn{1}{c}{1961} & 52.7 \\
\hline Litomyšl & 46,690 & 29,336 & 28,763 & 24,586 & 63.1 \\
Polička & 33,070 & 28,734 & 28,309 & 20,864 & 77.1 \\
Moravská Třebová & 37,797 & 32,695 & 32,393 & 29,125 & 79.0 \\
Svitavy & 38,949 & 28,382 & 29,641 & 30,767 & 67.3 \\
Total & 156,506 & 119,147 & 119,106 & 105,342 & 91.4 \\
Total Czech lands & $10,674,936$ & $8,765,230$ & $8,896,133$ & $9,756,429$ & \\
\hline
\end{tabular}

Source: State Statistical Office, 1935a,b, 1955, 1966; Census of Population in Czechoslovakia in 1946 and 1947, 1951; Modified by the author. NB: Districts in administrative organisation as of 1949 . 
economically and socially, the diversity of the population in a previously ethnically mixed area offers an opportunity to compare and confront ideas.

\section{Narrative interviews: conditions, course and findings}

Within the qualitative research, a total of twenty individual narrative interviews with eyewitnesses were carried out, mostly in nursing homes in Svitavy, Moravská Třebová, Litomyšl, and Polička. The potential communication partners were selected on the basis of the recommendations of hospital attendants, according to their health and willingness to communicate. About one third of the respondents, suggested by medical officers as appropriate people to carry out the interviews with, refused to participate in the interviews. The interviews took place in the afternoon (between 1 and 5 hours pm), usually in the room of the respondent or in the common room of a nursing home. So it was their natural environment, to which they were accustomed and which did not put them in a stressful situation. After being informed of the purpose of the interview for the needs of scientific research, and the anonymisation of sources, the communication partners gave us their consent to the realisation of the interviews. The average length of the interviews was three quarters of an hour up to an hour. Then the interviews were transcribed using the Atlas.ti software and the large amount of data thus acquired was further processed and filtered.

All the recordings and transcripts of the interviews are stored in the archive of the authors. From the large amount of information collected during the interviews we selected as relevant information only that related to the research topic. Any information concerning the personal life of the communication partners (many of them started talking about their youth, former occupation, family, etc.) and are not related directly to the research was filtered out. Of the twenty communication partners thirteen were born in the district of Svitavy and seven came from more distant regions of the country and participated in the resettlement of the district after the war.

The quality of the interviews varied because of the poor memory of some respondents, or their unwillingness to talk about certain topics (especially about events shortly after the Second World War and the relations with the Germans). It turned out that the biggest problem was the large amount of irrelevant information stemming from the need of the respondents "to tell the tale". Other issues that could have had a negative impact on the performance of the narrative interviews included the inadequate verbal skills associated with the advanced age of the respondents and possible partial errors in the processing and interpretation of the interviews. We tried to eliminate any potential errors occurring within the processing and interpretation of the interviews by a careful study of methodological procedures and thorough inspection of the transcripts of the interviews.

The face-to-face interviews provided us with the following information. All the witnesses, except for one, agreed with the transfer of the Germans from Czechoslovakia, in accordance with public opinion at that time, which strongly supported the transfer of the Sudeten Germans, regardless of their political affiliation. The nature of their statements indirectly indicates the importance of the role of the structures that had command of the mechanisms helping to influence the views of the population in general at that time. Obviously, the aim of these structures was to substantiate, justify, and defend the mass deportation.

"Transfer was righteous, it was not vengeance and it contributed to calming the situation down. It was a difficult time for the citizens of German nationality, but it was not easy even for people who came and took a step into the unknown." (male, b. 1914, Moravská Třebová). "I do not think that the transfer was fair; it was mostly those who were not at fault who had to leave-old men, women, and children. The Czechs plundered their assets, ravaged the borderlands, and displaced the experts. It was not right, but perhaps understandable, that hatred against the Germans was huge. Can we blame them, however, for succumbing to totalitarianism, when we succumbed to the same thing only ten years later?" (male, b. 1936, Polička) 
From these statements, on the other hand, the respondents' personal experience of the displacement processes is felt strongly. This was reflected, inter alia, by the fact, that although they agreed with the displacement, most of them sympathised with those who were displaced. For them, they were not nameless people, but neighbours. They realised that it was mostly single-parent families that were leaving, especially women, children, and old people, because the men were killed in the war, did not return, or were sent to labour camps.

In several cases, the Czech and German families lived together in one house before the transfer, which allowed them to establish distinct bonds with each other. The abovementioned situation was often found in the Polička region, where a detention camp for Germans was established. The interviews also often showed resentment over the looting of German property immediately after the war, during the so-called unorganised transfer.

\footnotetext{
"Most Germans had already left. An old grandmother lived next to us, she could barely walk or see, her son died in the war, but she had to go too. It was mostly the old people, women, and kids who had to go, I felt sorry for them." (female, b. 1936, Svitavy). "In June 1946, we moved from Borová to a semi-detached house in Pomezí. In the other part of the house, some Germans lived for a month and were waiting for transfer. Many other Germans were haughty or angry that they had to go away. But we got on well with 'our Germans'. They did not have anything valuable left in the house; they gave everything to Germans from mixed marriages who remained here. We did understand this... It was the end of June and the harvest began, there was nobody to reap. Then we drudged like never before. The first year we reaped for two farms. We paid, I think, 78,000 crowns for a house. But I know families who plundered the houses, and when they were supposed to pay for them, they left." (female, b. 1932, Pomezí). "The Germans had nice farms here. But those adventurers who came after them laid waste to them. Finally nearly all the houses were resettled; after all, we are not a borderland." (male, b. 1936, Polička)
}

The penultimate interview also illustrates well the expectations of new settlers regarding possessions to which they felt they had some legitimate right (see "they did not leave us anything of value in the house; they gave it to the Germans from mixed marriages who stayed here"). The narratives also document how the post-war events in the Svitavy region influenced the subsequent development of one of the key dimensions of the process of the formation of regional identity of the population, i.e. the so-called "idea of community" (PAAsI, A. 1986). The transformed post-war interaction between the Czech and German-speaking natives, and especially the new interaction between the Czech-speaking natives, German-speaking natives who did have to undergo resettlement (anti-fascists and Germans from mixed marriages), and the newly incoming residents, created quite specific conditions for transformation and for the establishment and subsequent reproduction of that "idea of community", whether in its ideal or factual nature.

The memories of the communication partners were more influenced by their current health status and former socioeconomic status than by their age or sex. In general, the better-educated people provided more complete and accurate statements, their insight into both processes was not only black and white, and they were also able to reflect on the negative consequences of the transfer of the Germans from the region.

A common feature of all the interviews was a reluctance to talk about the excesses, cruel events, and unorganised transfer. The communication partners preferred to talk about the war (e.g. about the arrival of the Russian army or the lack of food) than about the post-war events, which were harder to recall. Many respondents, even after repeated attempts to return to the theme, refused to talk about the events immediately after the Second World War, and especially those that occurred during the unorganised transfer. However, this topic is very sensitive, and to open it up requires the establishment of extraordinary confidence, which is difficult to gain in the short duration of one interview.

A significant difference lies in the territorial differentiation of the respondents. The majority of the eyewitnesses were born and lived 
in the regions of Polička and Litomyšl for the most of their lives. The Moravian part of the district, however, had a higher representation of communication partners who came to the region after the transfer. However, the frequent migration in the years 1945-1949 was typical for the whole region, as local residents who were not affected by the transfer of the Germans often participated in the resettlement process somewhere else.

We recorded a variety of views on the newly resettled population, but although the resettlement was finally successful according to the majority of the respondents, we noticed differences in the ratings between the residents and the new settlers. It can, therefore, be concluded that the different experiences of resettlement which are reflected in these statements correlate with the length of the stay of the inhabitants in the territory concerned.

The newcomers usually understood the resettlement as the beginning of a new life. It was an opportunity, especially for young couples who got married and could get a "starter" property or for families with small children. These groups are quite flexible and adaptable and from a distance they do not recall this period in a negative manner.

On the other hand, people who were born there perceived the new settlements of the region negatively and often pointed out that it took quite a long time (years) to consolidate conditions in the region and mentioned the occasional emigration of newcomers back to the areas of the country that are remote from the border or the unsuccessful settlement of several municipalities by foreign repatriated people. The narratives of the respondents in this case partly illustrate the importance of the length of their residence within the territory within the process of the population of the territory identifying with their lived space.

"Most of the new settlers came from Jaroměř, Vysočina, Nové Město na Moravě, and particularly from Bystřice nad Pernštejnem. The new residents assimilated quite well with each other. It was much worse in the Jeseník region, for example, where the Czech minority was weak. Today, the fourth generation lives here and nobody knows the word borderland." (male, b. 1924, Moravská Třebová)

From the interviews that were accomplished we can also read about the participation of the power structures in the process of identification of the inhabitants with their region. The methods by which these structures modified the economic character of the region, especially manifested in collectivisation, along with a negative attitude towards traditional cultural elements of the region, changed the value that the inhabited space represented for the local population. The transformation of the extent of the identification of the inhabitants with their region then corresponded with the symbolic shape of the region as transformed by the power structures.

"I've worked as a vet in Polička since 1961. I had, I think, nine German municipalities in my working area: Koclírov, Opatov, Opatovec, and Kamenná Horka in the Svitavy region and Pomezí, Květná, Stašov, Modřec, and Jedlová in the Polička region. Lots of Germans stayed in these villages; they were either from mixed marriages or they were anti-fascists. The rest of the population were the new settlers. In Koclírov, some Greeks and Yugoslavs came there. The communists founded collective farms, but the Germans did not want to join them. They regretted that they had stayed. In my opinion, the success of the resettlement was mainly negatively influenced by the communists. Their government had a negative impact on the overall level of the society, but in particular on the consolidation of the relationships in these municipalities. The old habits, customs, and traditions have never been restored, it was not desirable. And it makes a difference whether you are taking care of your own property or you have to be in a collective farm." (male, b. 1930, Litomyšl)

Another common feature of the interviews was the tendency of the respondents to enumerate the events of their lives without evaluating them. From the interviews, we learnt where they came here from, where they lived, where they then moved, who their neighbours were, etc., but not so much about their attitude to these events or what they meant for them.

"After the war, we also wanted a new house. We went to see Liberec. We stayed there with a German woman. She wanted us to plead for them so that they could stay here. 
She had two small children and her husband was killed at the front. But we could not do anything for them. My father was then looking for a house near Lanškroun, but my mother and us did not want to leave Rybná and eventually we stayed here. Many families, however, went to resettle." (male, b. 1924, Pustá Rybná)

The narrative interviews brought important findings for understanding whether the respondents, before the war and after it, maintained friendly relations with the German-speaking citizens. The interviews showed that, before the war, the respondents mostly had rather neutral or negative relationships with the Germans; friendly relationships were exceptional. Some respondents who participated in the settlement process experienced personal contacts with the German-speaking population only just after the war.

"My mother (born 1908, Polička) remembered how nobody liked the Germans here. They acted as if they were superior to us and grumbled at the lazy Czechs. Therefore, we did not talk to them. But, of course, some respectable German families lived here too." (female, b. 1941, Polička). Another woman (b. 1922), who lived in Hradec nad Svitavou (Gransdorf), where the German population prevailed, said: "We had no friendly relations with the Germans."

None of the respondents spoke of friendly relations with the Germans after the war. Only one woman (b. 1941, Polička) commented on the situation as follows:

\footnotetext{
"In Limerk (Pomezi), there were plenty of hard-working and decent Germans. We got food from a couple of them during the war. After the war, the situation obviously changed. But there were some Czechs who helped them. Mr. Dudek, an apothecary from Polička, gave them medicine for free while they were waiting for resettlement. But he was labelled a collaborator. He took it very hard and later, at a trial, he committed suicide, he shot himself..." The feelings of other respondents were sympathetic or rather negative. "Most Germans left. We lived next to an old grandmother; she could hardly walk and had poor sight, and her son died in the war, but she had to go, too. I felt really sorry for her." (female, b. 1936, Radiměř)
}

It is certain that the Czech-German relations did not definitively perish as a result of the resettlement of the Germans. Although they have undergone a substantial, mostly power-motivated transformation, they continue to develop in a transformed form. The personal post-war relations between the Czech-speaking population and the German-speaking population had two different forms in the Svitavy region. The first was based on personal contacts between the Czech residents and new settlers with the German-speaking natives who were not resettled. The data derived from narrative interviews may imply that it was not a very positive interaction:

"In 1961, I went to Moravská Třebová, to the cooperative farm. The people on the square still spoke German and did not want to tell me the way. That hostility was obvious." (female, b. 1941, Polička)

The second form was based on personal contacts between Czech residents and new settlers with the German-speaking people who were resettled after the war, and occasionally returned to their former homes later on, for example, the regular visits of the Sudeten Germans to their native villages or the well-attended Days of Czech-German Culture held annually in Moravská Třebová. This is demonstrated by the following:

"I also taught German children and children of mixed marriages who were waiting for resettlement. Some of them still come here and come to see me." (male, b. 1914, Moravská Třebová)

Therefore, it is evident that the process of the development of one of the crucial dimensions of regional identity of the inhabitants, the idea of community, had highly specific features, and not only in the period before World War II and the period immediately following the end of the war. Similarly, in the region in question, even a period quite far from the end of the war is quite distinctive regarding the coexistence of the Czechspeaking and German-speaking populations. It seems that here this coexistence had a rather dichotomous character in the sense of "us" and "them." Obviously, as a result of the resettlement, any interaction occurred to a 
lesser extent than it used to before. However, the role of these interactions in the process of the establishment of a specific form of the idea of community in the Svitavy region is evident.

\section{Discussion}

The survey being presented here, i.e. a research based on the experiences of natives with the resettlement of the German-speaking population and the colonisation process in the Svitavy region, is internationally rather exceptional and entirely unique in the Czech context, in terms of geographical science. A similar narrative research study took place on the Russian-Estonian border (PFoser, A. 2014). However, in the Czech Republic, there are no geographical projects that cover the personal experience of the inhabitants of the resettlement and new settlement of a specific region in the form of narrative interviews.

In the field of sociology, we can find several works that are directly related to the research topic of this paper and we can say that the findings of our survey conducted in the Svitavy region correspond with the findings of those works.

HoužvičKa and Novotný (2007) published a study which referred to research into the mutual perception of the inhabitants of Bavaria and Western Bohemia. The analysis of the impact of historical consciousness on the creation of regional identity was based on an empirical survey of biographical identities. The forms of cross-border cooperation and the mutual perception of Czechs and Germans were also evaluated. The motivation of the new settlers to come to the borderland instead of the former homes and the formation of their regional identity are described by ZICH, F. (2007). In his earlier works, ZICH $(2000,2006)$ also deals with regional identity of the population on the Czech-German border in connection with the origin of crossborder communities. However, the process of the formation of regional identity of the inhabitants of a particular region has never been surveyed using narrative interviews. This method, therefore, offers great research potential for the future.

\section{Conclusions}

The paper had two objectives. The first was to assess the importance of the method of narrative interviews for research on the formative factors of regional identity of a population. The latter was an evaluation of the specific formative factors of regional identity of the inhabitants, represented by the experience of witnesses to the resettlement of the Germanspeaking population and the process of new settlement in the Svitavy region. To meet the two objectives successfully, we formulated two research questions at the beginning of the paper to which we tried to find answers. With regard to these research questions, it is possible to state the following findings.

Despite some negative concomitant effects, the use of narrative interviews in research on the formative factors of regional identity of the population seems to be an appropriate complementary research method. These negative effects include a high amount of irrelevant information that the method generates. This irrelevant information must be eliminated, which quite considerably complicates the processing of the relevant data. It is also necessary to mention the aspect of the (dis)trust of respondents, which influences the character of the required data quite significantly. It is absolutely essential to establish mutual trust between the researcher and the interviewee, which in itself requires a certain time and is not always feasible. However, a suitable application of this method can detect experiences expressed in the memories of respondents. However, it is always an individual experience and its generalization is quite difficult. Therefore, narrative interviews cannot be considered to be a building block for research.

On the other hand, the number of witnesses who experienced the above-mentioned events is rapidly decreasing and we have one 
of the last opportunities to conduct research based on the narrative interview. It is necessary to keep in mind that it is a narrative of so-called "interested spectators", i.e. people who perceived the events of the time immediately and were not involved in the decision-making process. Through interviews, we can determine what the impact of the political decisions taken then on citizens were at the local level and whether the information listed in the primary sources and literature matches the statements of the witnesses.

Considering the second research question, we can state that the majority of the respondents agreed with the resettlement of the Germans; however, they did not conceal their sorrow over the course of post-war events and the form of the resettlement. This sorrow was expressed despite the probably not very harmonious coexistence of the Czech-speaking and German-speaking inhabitants of the region in the period before the post-war resettlement, which is implied by the narratives of some respondents. It is clear that for many natives, the German residents were not strangers but neighbours who they knew very well. Many respondents also talked about the effects of resettlement on farming and industry and about the socalled "gold-diggers" who enriched themselves at the expense of the Germans. The data obtained from the interviews confirmed that the relations between the Czech-speaking and German-speaking inhabitants in the Svitavy region did not perish even after the resettlement. It does not seem, however, that there were optimal relations between the post-war Czech population and those Germans who were not resettled. The respondents showed in the interviews that for many of them this is still a sensitive topic, or even a taboo, even after more than sixty years. The acquired knowledge, thus, points to very specific conditions of the formation of the idea of community as a key dimension of regional identity of the population.

Considering the second research question, we can state that the presentation of the respondents' experience of the resettlement process was not such a difficult task. The recorded statements evidence the post-war transformation of a number of key dimensions of the complex phenomena of regional identity. This was particularly obvious in relation to developmental changes in the process of the identification of the population with their territory, or in the "idea of community" processes. The interviews, then, reflect the post-war transformation of the symbolic shape of the region of Svitavy. The method of narrative interview that was applied, or rather the findings that were obtained by this method, indicate differences in declared experiences in terms of the dichotomy of natives or indigenous inhabitants vs. newcomers. This knowledge can be used in a discussion of the importance of the sociohistorical development of the region for the formation of the sense of regional identity of its inhabitants.

As a conclusion, it is clear that if we want to get a more complete view of the process of the formation, as well as the current form, of regional identity of the population of the Svitavy region, it is of course necessary to extend our current knowledge. The same is also true for more general statements relating to the role of the continuity of socio-historical development in the process of the formation of regional identities of the population. Another suitable research approach in this context seems to be narrative interviews with German-speaking people who were transferred from the Svitavy region. It is evident that the links of these people to the Svitavy region have not disappeared, but continue to develop in a certain form. Examples include the visits of Sudeten Germans to their native villages and the annual days of Czech-German culture in Moravská Třebová. Another suitable method for the enhancement of existing knowledge could be a field survey of a qualitative-quantitative nature of the current population of the Svitavy region. 


\section{REFERENCES}

Antonsich, M. 2010. Exploring the correspondence between regional forms of governance and regional identity: The case of Western Europe. European Urban and Regional Studies 17. (3): 261-276.

Arburg von, A. and StaněK, T. 2010. Vysídlení Němců a proměny českého pohraničí 1945-1951: dokumenty z českých archivư. Díl I., Češi a Němci do roku 1945: úvod k edici. 1.vyd., Středokluky, Zdeněk Susa, 373 p.

Atkinson, R. 2001. The Life Story Interview. In Handbook of interview research: Context $\mathcal{E}$ methods. Eds.: Gubrium, J.F. and Holstein, J.A. Thousand Oaks, SAGE Publications, 121-140.

BATES, J.A. 2005. Use of narrative interviewing in everyday information behavior research. Library and Information Science Research 26. (1): 15-28.

BENEš, Z. 2002. Rozumět dějinám: vývoj česko-německých vztahů na našem území v letech 1848-1948. Praha, Gallery, 304 p.

ČAPKA, F., SlezÁK, L. and VACulík, J. 2005. Nové osídlení pohraničí českých zemí po druhé světové válce. Brno, CERM, 359 p.

Čermák, I., HileEs, D. and Chrz, V. 2007. Narativně orientovaný výzkum: Interpretační perspektivy. In Sborník $z$ konference Kvalitativní prístup a metody ve vědách o člověku VI. Psychologica 37. Eds.: ŘEHAN, V. and ŠUCHA, M., Olomouc, Univerzita Palackého, 53-66.

Cerulo, K.A. 1997. Identity construction: New issues, new directions. Annual Review of Sociology 23. 385-409.

Cнromý, P. 2003. Formování regionální identity: nezbytná součást geografických výzkumů. In Geografie na cestách poznání. Eds.: Jančák, V., Chromý, P. and Marada, M. Praha, Univerzita Karlova v Praze, 163-178.

Chromý, P. and Skála, J. 2010. Kulturně geografické aspekty rozvoje př́hraničních periferií: analýza vybraných složek územní identity obyvatelstva Sušicka. Geografie 115. (2): 223-246.

DANĚK, P. 2000. Existuje politická kultura českého pohraničí? Geografie 105. (1): 50-62.

DANIEL, J. 2013. Reconstruction of the discussion on the final delimitation of regions in the year 1949: a contribution to the development of the regional administrative division of the Czech lands. Acta Universitatis Palackianae Olomucensis - Geographica. 44. (2): 111-124.

Dunn, K. 2005. Interviewing. In Qualitative Research Methods in Human Geography. $2^{\text {nd }}$ edition. Ed.: Hay, I. Melbourne, Oxford University Press, 79-105.

Everetr, S. and Aitchison, C. 2008. The Role of Food Tourism in Sustaining Regional Identity: A Case Study of Cornwall, South West England. Journal of Sustainable Tourism 16. (2): 150-167.

Fikejz, R. 2003. Historie a současnost podnikání na Svitavsku, Litomyšlsku, Poličsku, Moravskotřebovsku a Jevíčsku. 1.vyd., Žehušice, Městské knihy, 207 p.
Given, L.M. 2008. The SAGE Encyclopedia of Qualitative Research Methods, Los Angeles, Calif., Sage Publications, $1072 \mathrm{p}$.

Graham, B. 2000. The past in place: historical geographies of identity. In Modern Historical Geographies. Ed. Graham, B. Harlow, Pearson Education Ltd., 70-99.

Hendl, J. 1997. Úvod do kvalitativního výzkumu. Praha, Karolinum, 243 p.

Hendu, J. 2005. Kvalitativní výzkum: základní metody a aplikace. Praha, Portál, 407 p.

Hendl, J. 2008. Kvalitativní výzkum: základní teorie, metody a aplikace. Praha, Portál, 407 p.

HoužvičKA, V. and Novotný, L. eds. 2007. Otisky historie v regionálních identitách obyvatel pohraničí: sebedefinice a vzájemné vnímání Čechů a Němců v př́mém sousedství. Praha, Sociologický ústav, $170 \mathrm{p}$.

Jovchelovitch, S. and Bauer, M.W. 2000. Narrative interviewing. London, LSE Research Online, 1-14.

KáŇA, O. 1976. Historické proměny pohraničí: Vývoj pohraničních okresů Jeseník, Rýmařov, Bruntál a Krnov po roce 1945. Ostrava, Profil, $171 \mathrm{p}$.

Kneafsey, M. 2000. Tourism, Place Identities and Social Relations in the European Rural Periphery. European Urban and Regional Studies 7. (1): 35-50.

KRÁL, V. 1992. Rehabilitujme název Sudety. Geografické rozhledy 2. (4): p. 105.

Kučera, Z. and Kučerová, S. 2012. Historical geography of persistence, destruction and creation: The case of rural landscape transformations in Czechia's resettled borderland. Historická geografie 38. (1): 165-184.

Kural, V. 1994. Místo společenství - konflikt! Češi a Němci ve Velkoněmecké říši a cesta k odsunu (19381945). Praha, Ústav mezinárodních vztahů, 295 p.

Longhurst, R. 2010. Semi-structured Interviews and Focus Groups. In Key Methods in Geography. Eds.: Clifford, N., French, S. and Valentine, G. London, SAGE Publications, 103-115.

Macková, M. 2009. Správní hranice a proměny jejího významu pro region (na príkladu Hřebečska). Regiony - časoprostorové průsečíky. Praha, Historický ústav, 152-158.

Macleod, G. 1998. In what sence a region? Place hybridity, symbolic shape and institutional formation in (post-)modern Scotland. Political geography 17. (7): 833-863.

Maslow, A.H. 1943. A Theory of Human Motivation. Originally published: Psychological Review 5. 370396. (online) (cit. 2014-03-15). http://psychclassics. yorku.ca/Maslow/motivation

PAAsI, A. 1986. The institutionalization of regions: a theoretical framework for understanding the emergence of regions and the constitution of regional identity. Fennia 164. (1): 105-146.

PAAsi, A. 2002. Place and region: regional worlds and words. Progress in Human Geography 26. (6): 802-811. 
Pfoser, A. 2014. Between Russia and Estonia: narratives of place in a new borderland. Nationalities Papers 42. (2): 269-285.

PRED, A. 1984. Place as historically contingent process: structuration and the time-geography of becoming places. Annals of the Association of American Geographers 74. (2): 279-297.

Relph, E. 1976. Place and Placelessness. London, Pion. Schütze, F. 1987. Das narrative Interview in Interaktionsfeldstudien. In Das narrative Interview in Interaktionsfeldstudien: Erzählteoretische Grundlagen, Ed.: Sснüтze, F. Hagen, Fernuniversität-Gesamtschule in Hagen, 237-259.

ŠERÝ, M. 2014. The identification of residents with their region and the continuity of socio-historical development. Moravian Geographical Reports 22. (3): 53-64.

ŠERÝ, M. and ŠIMÁČEK, P. 2013. Vnímání hranic obyvatelstvem regionů s rozdílnou kontinuitou socio-historického vývoje jako dílčí aspekt jejich regionální identity. Geografie 118. (4): 392-414.

SKřIváneK, M. 1995. Odsun Němců ze Svitavska 19451947. Dissertationes historicae 4.123 p.

StANĚK, T. 1991. Odsun Němců z Československa 19451947. 1. Vyd., Praha, Academia, 536 p.

Thrift, N. 1983. On the determination of social action in space and time. Environment and Planning $D$. Society and space 1. 23-57.

Tuan, Y.-F. 1974. Space and place: Humanistic perspective. Progress in Geography 6. 211-252.

VAINIKKA, J. 2012. Narrative claims on regions: prospecting for spatial identities among social movements in Finland. Social and Cultural Geography 13. (6): 587-605.

Velešík, V. 2000. Osídlování Svitavska v letech 1945-1947. Pomezí Čech a Moravy: Sborník prací ze společenských a př́rodních věd pro okres Svitavy. Svazek 4, Litomyšl, Státní okresní archiv Svitavy se sídlem v Litomyšli, 199-268.

Wengraf, T. 2001. Qualitative Research Interviewing: Biographic Narrative and Semi-Structured Methods. London, SAGE Publications, 378 p.

Wiles, J. L., Rosenberg, M. W. and Kearns, R.A. 2005. Narrative analysis as a strategy for understanding interview talk in geographic research. Area 37. (1): 89-99.
ZICH, F. 2000. Vytváření přeshraničního společenství na česko-německé hranici. Ústí nad Labem, Sociologický ústav Akademie věd České republiky, 271 p.

ZICH, F. 2006. Člověk v pohraničí: výzkum preshraničních vlivư pusobících na obyvatele pohraničí ČR. Ústí nad Labem, Univerzita J. E. Purkyně, 262 p.

ZıсH, F. 2007. Regionální identita obyvatel českého západního pohraničí. In Otisky historie v regionálních identitách obyvatel pohraničí. Eds.. HoužvičKA, V., and Novotný, L. Praha, SOÚ, 49-64.

Zimmerbauer, K. 2011. From image to identity: building regions by place promotion. European Planning Studies 19. (2): 243-260.

\section{STATISTICAL RESOURCES:}

Soupisy obyvatelstva v Československu v letech 1946 a 1947. Praha, Státní úřad statistický, 1951, 536 p.

State Statistical Office, 1934. „Statistický lexikon obcí v republice Československé 1930. 1: země česká", Praha, Státní úřad statistický, 631 p.

State Statistical Office, 1935a. „Statistický lexikon obcí v republice Československé 1930. 2: země Moravskoslezská", Praha, Státní úřad statistický, 212 p.

State Statistical Office, 1935b. „Sčítání lidu v republice Československé ze dne 1. prosince 1930. Díl II. Povolání obyvatelstva. Č́st 2", Praha, Státní úřad statistický, 419 p.

State Statistical Office, 1946. „Seznam obcí v zemi České (resp. Moravskoslezské) podle stavu z 1 . Prosince 1945", in Zprávy Státního úřadu statistického, vol. 1946, no. 1-16 (Čechy) a 17-22 (Morava a Slezsko). Správní uspořádání z prosince 1945, počet obyvatelstva podle 7. Zásobovacího období.

State Statistical Office, 1955. „Statistický lexikon obcí Republiky československé 1955: podle správního rozdělení 1. ledna 1955, sčítání lidu, sčítání domů a bytů 1. března 1950“",Praha, Statistické a evidenční vydavatelství tiskopisů, 574 p.

State Statistical Office, 1966. „Statistický lexikon obcí ČSSR 1965: podle správního rozdělení 1. ledna 1965, sčítání lidu, domů a bytů 1. března1961“, Praha, Statistické a evidenční vydavatelství tiskopisů, 668 p. 